\title{
Effect of timing of whey protein supplement on muscle damage markers after eccentric exercise
}

\author{
Jooyoung Kim, Chulhyun Lee, Joohyung Lee* \\ Sport, Health and Rehabilitation Major, College of Physical Education, Kookmin University, Seoul, Korea
}

Whey protein is a nutritional supplement commonly ingested for recovery following exercise. However, the timing when whey protein supplement must be ingested after muscle-damaging exercise is debatable. Therefore, the present study investigated the effects of the timing of supplement ingestion on muscle damage markers after eccentric or muscle-damaging exercise. In total, 32 collegiate male students participated in this study; they were randomly assigned to control group $(n=8)$, before supplement group $(n=8)$, after supplement group $(n=8)$, or before and after supplement group $(n=8)$. Eccentric exercise was performed using elbow flexors with a modified preacher curl machine. Subsequently, maximal isometric strength, muscle soreness, range of motion (relaxed and flexed arm angle), and blood markers (creatine kinase and aspartate transaminase) were measured before and after exercise. Repeated-measure analysis of variance was used to analyze the effects of timing of supplement. No significant group by time effects were noted in maximal isometric strength, muscle soreness, range of motion, and blood markers $(P>0.05)$. The timing of whey protein supplement did not affect reduction of muscle damage or recovery following eccentric exercise.

Keywords: Eccentric exercise, Muscle damage, Timing of supplement, Whey protein

\section{INTRODUCTION}

It is well known that repeated high-force eccentric exercise induces muscle damage (Chen et al., 2011). Muscle damage reduces maximal isometric strength and range of motion (ROM) and increases muscle soreness and blood markers such as creatine kinase (CK) (Clarkson and Hubal, 2002). In addition, damaged muscle tissue results in muscle degeneration by degradation of structural proteins, including myofibrils and cytoskeletal proteins (Phillips et al., 1997). Whey protein is commonly ingested after exercise, and it has been used as a supplement to prevent muscle degeneration and to increase protein synthesis (Cooke et al., 2010). Whey protein is a protein extract from coagulation by-products when milk is coagulated during the process of cheese production and includes several essential amino acids that are easily digested and absorbed (Mahé et al., 1996).

Several studies have reported that whey protein supplements after exercise are beneficial to facilitate recovery by increasing pro- tein synthesis and reducing muscle damage (Buckley et al., 2010; Cooke et al., 2010). In contrast, whey protein supplements before resistance exercise has been reported to increase protein synthesis and muscle regeneration (Witard et al., 2009). In addition, consumption of protein supplements rich in essential amino acids before resistance exercise had greater effects on amino acids levels and protein synthesis than did their consumption after exercise (Tipton et al., 2001). On the other hand, a recent study showed that whey protein supplements before and after exercise promoted recovery from resistance exercise (Hoffman et al., 2010). Based on results of previous studies where the type of exercise was mostly resistance exercise, which may not always induce muscle damage, it is unclear whether the timing of whey protein supplement might have any effect on reduction of muscle damage or recovery from muscle-damaging exercise. Therefore, the present study investigated the effects of the timing of whey protein supplement ingestion on muscle damage markers following eccentric exercise.

\footnotetext{
${ }^{*}$ Corresponding author: Joohyung Lee (iD https://orcid.org/0000-0001-8279-3830 Sport, Health and Rehabilitation Major, College of Physical Education, Kookmin University, 77 Jeongneung-ro, Seongbuk-gu, Seoul 02707, Korea Tel: +82-2-910-4782, Fax: +82-2-910-4789, E-mail: jolee@kookmin.ac.kr Received: June 23, 2017 / Accepted: August 10, 2017
}

This is an Open Access article distributed under the terms of the Creative Commons Attribution Non-Commercial License (http://creativecommons.org/licenses/by-nc/4.0/) which permits unrestricted non-commercial use, distribution, and reproduction in any medium, provided the original work is properly cited. 


\section{MATERIALS AND METHODS}

\section{Subjects}

In total, 32 male collegiate students who had not participated in any exercise program in the past 6 months, were nonsmokers, and had not consumed any supplements with protein or vitamin products were included in the study. Each subject was explained the purpose of the study as well as all study procedures before obtaining a signed informed consent form. Each subject was randomly assigned to either control, before supplement group (BSG), after supplement group (ASG), or before and after supplement group (MSG). Subject characteristics are summarized in Table 1.

\section{Body composition}

Body composition was measured using a bioelectrical impedance instrument (InBody 520, Biospace, Seoul, Korea). Before measurement, each subject was requested to fast overnight and to abstain from intense exercise or sauna.

\section{Whey protein supplement}

Whey protein supplement was ingested in powder form $(1.5 \mathrm{~g} /$ $\mathrm{kg}$ ) mixed with $300 \mathrm{~mL}$ of plain water. BSG was supplemented $10 \mathrm{~min}$ before exercise, ASG $10 \mathrm{~min}$ after exercise, and MSG 10 min before and after exercise. The control group did not ingest any supplement during the experiment. Each subject was requested to ingest ordinary meals until the experiment was completed and to abstain from excess protein consumption. Each subject recorded his daily dietary intake and was requested to submit these records at the end of the experiment.

\section{Eccentric exercise}

Eccentric exercise comprised two sets of 25 eccentric contractions of elbow flexors by using a modified preacher curl machine, wherein each subject was seated on the machine with his chest and arm placed on the pad. While the investigator pushed down the lever attached to the machine, each subject pulled his arm

Table 1. Characteristics of subjects

\begin{tabular}{lcccc}
\hline Group & Age $(\mathrm{yr})$ & Height $(\mathrm{cm})$ & Weight $(\mathrm{kg})$ & Body fat $(\%)$ \\
\hline CON $(n=8)$ & $23.0 \pm 2.9$ & $174.2 \pm 4.7$ & $71.3 \pm 5.6$ & $19.7 \pm 5.9$ \\
BSG $(n=8)$ & $23.1 \pm 1.9$ & $176.7 \pm 6.4$ & $69.0 \pm 7.3$ & $14.7 \pm 3.8$ \\
ASG $(n=8)$ & $22.7 \pm 3.6$ & $172.0 \pm 6.0$ & $69.0 \pm 8.3$ & $18.8 \pm 4.6$ \\
MSG $(n=8)$ & $23.62 \pm 2.2$ & $176.1 \pm 4.1$ & $69.6 \pm 5.1$ & $15.3 \pm 3.9$ \\
\hline
\end{tabular}

Values are presented as mean \pm standard deviation. CON, control; BSG, before supplement group; ASG, after supplement group; MSG, before and after supplement group. maximally to perform eccentric contractions (Clarkson et al., 2005).

\section{Maximal isometric strength}

Maximal isometric strength of the elbow flexors was recorded using a strain gauge (PKS-1250, Poong Kwang, Seoul, Korea) attached to the modified preacher curl machine. Three sets of measurements were recorded each before, immediately after and 24 , 48, 72, and $96 \mathrm{hr}$ after exercise.

\section{Muscle soreness}

Muscle soreness was determined using a visual analog scale, wherein 0 indicated no soreness and 10 indicated severe soreness. Muscle soreness was measured before and 24, 48, 72, and $96 \mathrm{hr}$ after exercise.

\section{Range of motion}

ROM was measured using a goniometer (S29-5900, KASCO, Islamabad, Pakistan). Both relaxed- and flexed-arm angles were measured when the elbow was completely relaxed and flexed, respectively, before, immediately after and 24, 48, 72, and $96 \mathrm{hr}$ after exercise.

\section{Blood markers}

Blood samples $(5 \mathrm{~mL})$ were obtained from antecubital vein before and 24, 48, 72, and $96 \mathrm{hr}$ after exercise to analyze $\mathrm{CK}$ and aspartate transaminase. In order to collect serum, sample vials were centrifuged at approximately 2,500-3,000 rpm; subsequently, the serum was transferred into a microtube and stored at $-80^{\circ} \mathrm{C}$ in a freezer (Ultra-Low Temperature Freezer, OPERON, Gimpo, Korea) until these were evaluated in an automatic blood sample analyzer (DT60II, Johnson \& Johnson, Minneapolis, MN, USA).

\section{Statistical analysis}

All parameters were indicated as mean and standard deviation. By using the IBM SPSS Statistics ver. 21.0 (IBM Co., Armonk, $\mathrm{NY}$, USA), repeated-measure analysis of variance was used to analyze the groups by time interactions. Significance was set at 0.05 .

\section{RESULTS}

Maximal isometric strength and ROM were significantly reduced following eccentric exercise $(P<0.001)$, while muscle soreness and blood markers were significantly increased after exercise $(P<0.001)$. However, there were no significant effects of the tim- 
Kim J, et al. - Whey protein supplement and muscle damage

Table 2. Change of maximal isometric strength (\%) after eccentric exercise

\begin{tabular}{|c|c|c|c|c|c|c|c|}
\hline Group & Pre & Post & $24 \mathrm{hr}$ & $48 \mathrm{hr}$ & $72 \mathrm{hr}$ & $96 \mathrm{hr}$ & $P$-value \\
\hline $\operatorname{CON}(n=8)$ & $100.0 \pm 0.0$ & $38.1 \pm 16.5$ & $37.8 \pm 12.4$ & $39.0 \pm 15.2$ & $43.5 \pm 14.2$ & $45.0 \pm 15.1$ & 0.516 \\
\hline $\mathrm{BSG}(\mathrm{n}=8)$ & $100.0 \pm 0.0$ & $43.3 \pm 15.1$ & $49.2 \pm 15.3$ & $57.8 \pm 21.7$ & $57.6 \pm 13.8$ & $63.9 \pm 18.7$ & \\
\hline ASG $(n=8)$ & $100.0 \pm 0.0$ & $40.3 \pm 20.0$ & $42.6 \pm 15.5$ & $47.8 \pm 20.6$ & $48.3 \pm 23.2$ & $56.7 \pm 35.4$ & \\
\hline MSG (n=8) & $100.0 \pm 0.0$ & $39.2 \pm 18.8$ & $39.3 \pm 23.8$ & $41.8 \pm 17.8$ & $50.5 \pm 17.6$ & $49.6 \pm 18.0$ & \\
\hline
\end{tabular}

Values are presented as mean \pm standard deviation.

CON, control; BSG, before supplement group; ASG, after supplement group; MSG, before and after supplement group.

Table 3. Change of muscle soreness ( $\mathrm{mm}$ ) after eccentric exercise

\begin{tabular}{lccccc}
\hline Group & Pre & $24 \mathrm{hr}$ & $48 \mathrm{hr}$ & $72 \mathrm{hr}$ & $96 \mathrm{hr}$ \\
\hline CON $(\mathrm{n}=8)$ & $0.0 \pm 0.0$ & $47.6 \pm 7.9$ & $64.5 \pm 11.0$ & $63.7 \pm 16.8$ & $35.6 \pm 17.0$ \\
BSG $(\mathrm{n}=8)$ & $0.0 \pm 0.0$ & $47.5 \pm 19.8$ & $53.2 \pm 19.4$ & $52.5 \pm 22.6$ & $32.3 \pm 21.0$ \\
ASG $(\mathrm{n}=8)$ & $0.0 \pm 0.0$ & $54.5 \pm 21.2$ & $57.6 \pm 23.7$ & $46.2 \pm 27.0$ & $31.1 \pm 26.2$ \\
MSG $(\mathrm{n}=8)$ & $0.0 \pm 0.0$ & $52.7 \pm 25.2$ & $66.5 \pm 20.3$ & $55.0 \pm 9.8$ & $34.0 \pm 13.1$ \\
\hline
\end{tabular}

Values are presented as mean \pm standard deviation.

CON, control; BSG, before supplement group; ASG, after supplement group; MSG, before and after supplement group.

Table 4. Change of relaxed arm angle $\left({ }^{\circ}\right)$ after eccentric exercise

\begin{tabular}{lccccccc}
\hline Group & Pre & Post & $24 \mathrm{hr}$ & $48 \mathrm{hr}$ & $72 \mathrm{hr}$ & $96 \mathrm{hr}$ & $P$-value \\
\hline CON $(\mathrm{n}=8)$ & $154.9 \pm 7.4$ & $142.1 \pm 4.8$ & $141.0 \pm 4.2$ & $136.5 \pm 6.9$ & $135.8 \pm 7.0$ & $140.8 \pm 6.9$ & 0.533 \\
BSG $(\mathrm{n}=8)$ & $151.3 \pm 6.7$ & $141.8 \pm 5.9$ & $139.2 \pm 7.4$ & $141.0 \pm 5.2$ & $142.8 \pm 5.3$ & $145.3 \pm 4.9$ & $136.8 \pm 18.8$ \\
ASG $(\mathrm{n}=8)$ & $149.5 \pm 4.3$ & $137.7 \pm 9.6$ & $136.1 \pm 8.4$ & $135.3 \pm 12.2$ & $136.5 \pm 14.2$ & 138.2 \\
MSG $(n=8)$ & $147.8 \pm 5.1$ & $135.2 \pm 9.8$ & $132.8 \pm 6.7$ & $130.0 \pm 7.3$ & $133.5 \pm 10.5$ & $138.6 \pm 13.1$ \\
\hline
\end{tabular}

Values are presented as mean \pm standard deviation.

CON, control; BSG, before supplement group; ASG, after supplement group; MSG, before and after supplement group.

Table 5. Change of flexed arm angle $\left({ }^{\circ}\right)$ after eccentric exercise

\begin{tabular}{|c|c|c|c|c|c|c|c|}
\hline Group & Pre & Post & $24 \mathrm{hr}$ & $48 \mathrm{hr}$ & $72 \mathrm{hr}$ & $96 \mathrm{hr}$ & $P$-value \\
\hline $\operatorname{CON}(n=8)$ & $37.0 \pm 4.0$ & $52.3 \pm 8.3$ & $48.6 \pm 6.8$ & $48.3 \pm 5.1$ & $49.7 \pm 5.7$ & $48.7 \pm 6.7$ & 0.299 \\
\hline BSG $(n=8)$ & $40.3 \pm 4.5$ & $50.4 \pm 4.3$ & $45.5 \pm 5.4$ & $45.7 \pm 6.0$ & $46.2 \pm 5.8$ & $43.6 \pm 3.7$ & \\
\hline ASG $(n=8)$ & $37.9 \pm 5.5$ & $51.6 \pm 13.6$ & $48.0 \pm 14.2$ & $48.0 \pm 12.2$ & $49.5 \pm 14.8$ & $48.2 \pm 10.3$ & \\
\hline MSG $(n=8)$ & $37.4 \pm 3.8$ & $48.6 \pm 5.8$ & $46.9 \pm 3.9$ & $49.0 \pm 2.9$ & $47.2 \pm 3.1$ & $46.0 \pm 3.1$ & \\
\hline
\end{tabular}

Values are presented as mean \pm standard deviation.

CON, control; BSG, before supplement group; ASG, after supplement group; MSG, before and after supplement group.

ing of supplement ingestion on maximal isometric strength ( $P=0.516)$, ROM, muscle soreness $(P=0.791)$, and blood markers following eccentric exercise. The results are presented in Tables 2-7.

\section{DISCUSSION}

The present study investigated whether the timing of whey protein supplement can affect muscle damage markers after eccentric exercise; however, the results revealed no significant effects of the timing of ingestion on muscle damage markers after exercise. These results are not concordant with those reported in previous studies. Buckley et al. (2010) and Cooke et al. (2010) reported that whey protein supplements consumed after eccentric exercise resulted in faster recovery of muscle strength. However, there was a difference in the frequency of supplement ingestion between previous studies and the present study. In the study conducted by Buckley et al. (2010), subjects ingested whey protein immediately after and 6 and $24 \mathrm{hr}$ after eccentric exercise, while the study by Cooke et al. (2010) revealed significant effects of whey protein supplement ingested 4 times/day for 2 weeks after eccentric exercise. However, in the present study, one dose each was ingested before, after, or before and after eccentric exercise. In fact, several 
Kim J, et al. • Whey protein supplement and muscle damage

Table 6. Change of creatine kinase (U/L) after eccentric exercise

\begin{tabular}{lcccccc}
\hline Group & Pre & $24 \mathrm{hr}$ & $48 \mathrm{hr}$ & $72 \mathrm{hr}$ & $96 \mathrm{hr}$ & $P$-value \\
\hline CON $(n=8)$ & $215.8 \pm 249.0$ & $1,703.7 \pm 2,978.0$ & $5,864.7 \pm 5,412.1$ & $22,813.0 \pm 22,662.8$ & $30,228.5 \pm 22,937.5$ \\
BSG $(n=8)$ & $76.4 \pm 53.6$ & $1,127.3 \pm 2,541.6$ & $4,176.5 \pm 9,380.5$ & $7,702.5 \pm 9,268.4$ & $10,860.4 \pm 10,514.7$ \\
ASG $(n=8)$ & $102.5 \pm 73.4$ & $440.3 \pm 476.3$ & $2,103.3 \pm 3,471.1$ & $14,069.2 \pm 18,504.4$ & $18,980.7 \pm 19,912.9$ \\
MSG $(n=8)$ & $123.6 \pm 62.3$ & $2,175.6 \pm 3,047.5$ & $9,433.5 \pm 11,490.4$ & $23,322.2 \pm 21,945.7$ & $41,186.0 \pm 51,976.7$ \\
\hline
\end{tabular}

Values are presented as mean \pm standard deviation.

CON, control; BSG, before supplement group; ASG, after supplement group; MSG, before and after supplement group.

Table 7. Change of aspartate aminotransferase (U/L) after eccentric exercise

\begin{tabular}{lccccc}
\hline Group & Pre & $24 \mathrm{hr}$ & $48 \mathrm{hr}$ & $72 \mathrm{hr}$ & $96 \mathrm{hr}$ \\
\hline CON $(\mathrm{n}=8)$ & $41.5 \pm 12.2$ & $53.1 \pm 30.8$ & $72.8 \pm 31.1$ & $142.1 \pm 81.9$ & $186.5 \pm 103.2$ \\
BSG $(\mathrm{n}=8)$ & $29.7 \pm 12.9$ & $37.4 \pm 17.1$ & $73.0 \pm 75.5$ & $129.2 \pm 122.0$ & $174.3 \pm 166.9$ \\
ASG $(\mathrm{n}=8)$ & $35.7 \pm 16.3$ & $42.2 \pm 22.7$ & $45.5 \pm 30.1$ & $108.7 \pm 98.3$ & $174.8 \pm 151.4$ \\
MSG $(n=8)$ & $36.0 \pm 25.1$ & $52.1 \pm 26.5$ & $112.3 \pm 97.2$ & $194.7 \pm 135.3$ & $259.5 \pm 162.0$ \\
\hline
\end{tabular}

Values are presented as mean \pm standard deviation.

CON, control; BSG, before supplement group; ASG, after supplement group; MSG, before and after supplement group.

studies with a single dose of whey protein supplement have reported results similar to those of our study. Burnley et al. (2010) reported that a single dose of whey protein supplement after eccentric exercise did not improve muscle soreness and CK activity. In addition, White et al. (2008) reported that whey protein supplement before or after eccentric exercise did not influence any muscle damage markers. In contrast, a recent study demonstrated that whey protein supplement consumed after eccentric exercise for 7 days resulted in increased fibroblast proliferation and faster muscle strength recovery after exercise. This implies that the period of supplementation may be more important than the timing of supplement ingestion.

The difference between the present study and other previous studies may be attributed to the exercise protocol used in this study. Eccentric exercise with elbow flexors is known to produce greater muscle damage (Jamurtas et al., 2005) compared with exercise protocols with lower limb that use an isokinetic dynamometer or downhill running or walking on a treadmill (Jamurtas et al., 2005; Tiidus, 2008). Most previous studies had used isokinetic eccentric contractions of the lower limb (Buckley et al., 2010; Cooke et al., 2010; Dale et al., 2015). Moreover, certain other studies on effects of whey protein supplements had used lower-limb resistance exercises (Hoffman et al., 2010; Tipton et al., 2011; Witard et al., 2009). For instance, Buckley et al. (2010) reported that peak CK activity at $24 \mathrm{hr}$ after eccentric exercise ranged 196.5-386.8 U/L, while Hoffman et al. (2010) reported that the peak CK activity did not reach $250 \mathrm{U} / \mathrm{L}$ at $48 \mathrm{hr}$ after resistance exercise. In the present study, CK activity at $24 \mathrm{hr}$ after eccentric exercise ranged 440-2,175 U/L.

Greater muscle damage leading to protein degradation may require higher protein intake during the recovery period (Phillips and Van Loon, 2011). A universal resistance exercise also induces increased protein degradation until up to $48 \mathrm{hr}$ after exercise (Phillips et al., 1997). Therefore, sufficient intake of amino acids in the form of protein supplements is required to delay protein degradation and promote protein synthesis (Wagenmakers, 1999). In contrast, insufficient protein intake may delay recovery after exercise by increasing protein degradation, leading to a negative nitrogen balance (Rennie and Tipton, 2000).

In conclusion, a single dose of whey protein supplement, regardless of the timing of supplement ingestion, may not be beneficial after muscle-damaging exercise.

\section{CONFLICT OF INTEREST}

No potential conflict of interest relevant to this article was reported.

\section{REFERENCES}

Buckley JD, Thomson RL, Coates AM, Howe PR, DeNichilo MO, Rowney MK. Supplementation with a whey protein hydrolysate enhances recovery of muscle force-generating capacity following eccentric exercise. J Sci Med Sport 2010;13:178-181.

Burnley EC, Olson AN, Sharp RL, Baier SM, Alekel DL. Impact of protein supplements on muscle recovery after exercise-induced muscle sore- 
ness. J Exerc Sci Fit 2010;8:89-96.

Chen CH, Nosaka K, Chen HL, Lin MJ, Tseng KW, Chen TC. Effects of flexibility training on eccentric exercise-induced muscle damage. Med Sci Sports Exerc 2011;43:491-500.

Clarkson PM, Hoffman EP, Zambraski E, Gordish-Dressman H, Kearns A, Hubal M, Harmon B, Devaney JM. ACTN3 and MLCK genotype associations with exertional muscle damage. J Appl Physiol (1985) 2005;99:564-569.

Clarkson PM, Hubal MJ. Exercise-induced muscle damage in humans. Am J Phys Med Rehabil 2002;81(11 Suppl):S52-69.

Cooke MB, Rybalka E, Stathis CG, Cribb PJ, Hayes A. Whey protein isolate attenuates strength decline after eccentrically-induced muscle damage in healthy individuals. J Int Soc Sports Nutr 2010;7:30.

Dale MJ, Thomson RL, Coates AM, Howe PR, Brown A, Buckley JD. Protein hydrolysates and recovery of muscle damage following eccentric exercise. Funct Food Health Dis 2015;5:34-43.

Hoffman JR, Ratamess NA, Tranchina CP, Rashti SL, Kang J, Faigenbaum AD. Effect of a proprietary protein supplement on recovery indices following resistance exercise in strength/power athletes. Amino Acids 2010;38:771-778

Jamurtas AZ, Theocharis V, Tofas T, Tsiokanos A, Yfanti C, Paschalis V, Koutedakis $Y$, Nosaka K. Comparison between leg and arm eccentric exercises of the same relative intensity on indices of muscle damage. Eur J Appl Physiol 2005;95:179-185.

Mahé S, Roos N, Benamouzig R, Davin L, Luengo C, Gagnon L, Gaussergès N, Rautureau J, Tomé D. Gastrojejunal kinetics and the diges- tion of [15N]beta-lactoglobulin and casein in humans: the influence of the nature and quantity of the protein. Am J Clin Nutr 1996;63:546552.

Phillips SM, Tipton KD, Aarsland A, Wolf SE, Wolfe RR. Mixed muscle protein synthesis and breakdown after resistance exercise in humans. Am J Physiol 1997;273(1 Pt 1):E99-107.

Phillips SM, Van Loon LJ. Dietary protein for athletes: from requirements to optimum adaptation. J Sports Sci 2011;29 Suppl 1:S29-38.

Rennie MJ, Tipton KD. Protein and amino acid metabolism during and after exercise and the effects of nutrition. Annu Rev Nutr 2000;20:457483.

Tiidus PM. Skeletal muscle damage and repair. Champaign (IL): Human Kinetics; 2008.

Tipton KD, Rasmussen BB, Miller SL, Wolf SE, Owens-Stovall SK, Petrini $\mathrm{BE}$, Wolfe RR. Timing of amino acid-carbohydrate ingestion alters anabolic response of muscle to resistance exercise. Am J Physiol Endocrinol Metab 2001;281:E197-206.

Wagenmakers AJ. Tracers to investigate protein and amino acid metabolism in human subjects. Proc Nutr Soc 1999;58:987-1000.

White JP, Wilson JM, Austin KG, Greer BK, St John N, Panton LB. Effect of carbohydrate-protein supplement timing on acute exercise-induced muscle damage. J Int Soc Sports Nutr 2008;5:5.

Witard OC, Tieland M, Beelen M, Tipton KD, van Loon LJ, Koopman R. Resistance exercise increases postprandial muscle protein synthesis in humans. Med Sci Sports Exerc 2009;41:144-154. 